\title{
METHODS OF IMPROVING FOREIGN INVESTMENTS IN THE ECONOMY OF UZBEKISTAN
}

\author{
Jalilov Shokhrukh Zafar O'g'li, \\ Latipova Shakhnoza Makhmudovna
}

Uzbekistan, Samarkand, SIES

DOI: https://doi.org/10.31435/rsglobal_ijite/01062018/5651

\section{ARTICLE INFO}

Received 04 April 2018

Accepted 02 May 2018

Published 01 June 2018

KEYWORDS

"open door" policy, foreign

investment, economic policy, strategy, export opportunities, investment activity

\begin{abstract}
In article ways of development of economy of the Republic of Uzbekistan, improvement of attraction of foreign investments for the organization of the modern cooperation small enterprises making a finished product on the basis of processing of valuable raw materials and ensuring integration into world economy are stated.
\end{abstract}

(C) 2018 The Authors.

Introduction. In the context of economic liberalization, an effective social and economic policy of attracting foreign investment to our country plays a key role in deepening the accession of the Republic of Uzbekistan to the world community and strengthening its positions in the world market. This is based on the establishment of mutually beneficial foreign economic relations and the regular attraction of foreign investment using the experience of developed countries. The President's speech at the joint meeting of the Oliy Majlis of the Republic of Uzbekistan Shavkat Mirziyayev with the aim of further strengthening trade and economic relations with foreign countries by encouraging economic opportunities in the country and abroad to further enhance its international prestige, attract investment to accelerate the further development of the tourism industry, are defined in as a priority for us.

Of course, since modernization of our economy should become the priorities of economic policy, it is necessary to develop and further improve measures to stimulate production and investment activities. As mentioned above, it is necessary to bring in foreign technologies and create complex modern joint ventures, develop competitive products for the technical and technological renovation of enterprises and ensure their access to foreign markets.

Analysis of thematic issues. Among the scientific publications are devoted to the study of the economic content and nature of investment, along with foreign scientists from the CIS countries, including Russian economists P.I. Vakhrin and A.S. Neyshitoy [1], N.V. Igoshin [2], S.V. Valdaytsev, P.P. Vorobev and others [3]. Y.S. Melkumov [4], G.I. Ivanov [5], V.P. Zhdanov [6] conducted significant scientific research. Concerning scientific-practical issues of attracting investments and their effective use and regulation in the Uzbek economy, S.S. Gulyamov, M.K. Pardayev, O.Y. Rashidov, B.B.Berkinov, B.Goyibnazarov, D.G'. Gozibekov and others.

Particularly, this issue requires more attention, given the current liberalization of the economy. Given the current relevance of the problem, research has been deemed to be the subject of the research, goals and objectives.

As the priorities of Uzbekistan's economic policy are being determined in the first years of independence, development and deepening of the investment base are considered as a critical prerequisite for the reform strategy (Fig. 1).

As you know, no country in the world has been able to achieve development and economic development without attracting foreign investment [7]. Therefore, this work has become one of the priorities of the country's economic policy. In the Republic of Uzbekistan, this policy is based on the following principles:

- liberalization of foreign economic activity;

- the formation of a legal framework, socio-economic and other conditions that ensure the attraction of capital resources to the economy of the republic; 
- Regular maintenance of the open door policy with respect to foreign investors, promotion of technologies that meet international standards, and the promotion of modern economic structures;

- Expenditures on the most important priorities related to the development of competitive products.

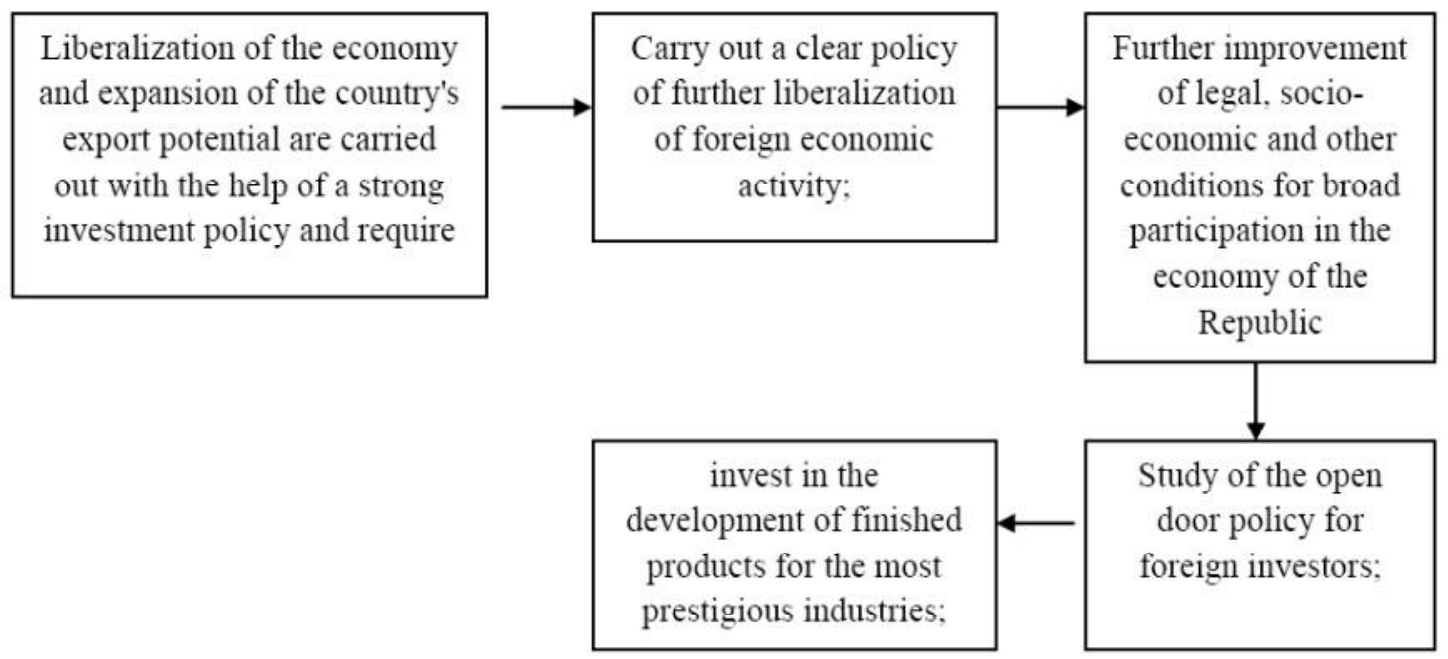

Fig. 1. Investment strategy development and deepening strategy in Uzbekistan

The current legislation in our country guarantees a number of guarantees and privileges to foreign investors. At the same time, recognizing the need for foreign investment in the economy: foreign investors should gain confidence in the investment policy pursued in the Republic of Uzbekistan, as a strong partner, able to solve the most important issues of the rule of law. To do this, it is necessary to create legal, social and other necessary conditions for the economy to attract foreign investment mainly in the form of direct investment, facilitate the creation of joint ventures, and improve the protection of investors' interests.

Of course, not every foreign investor investing in the country,

- First of all, the stability of the socio-political situation in the republic;

- clear clarity of the prospects for economic development;

- coherence of economic reforms in the republic; investment.

- They are also interested in the correctness of preferential terms of the legislation on foreign

Attracting foreign investment, it is difficult for companies to mobilize sources of domestic savings and make the task of transforming the structure of the economy into a radical transition without active investment. The main emphasis of investment policy should be to encourage enterprises to invest in the expansion of production, reconstruction and technical re-equipment.

Attracting foreign investments into the country's economy, our goal is to achieve our goal only by investing in foreign countries and turning it into a country that supplies raw materials.

Analysis and Results. At the initial stage of the reforms, the introduction of foreign investment in the national economy was described as the future of entrepreneurship [8]. The use of this opportunity was justified by the consequences. Practical steps were taken to solve the identified measures and tasks. Based on the predefined principles of implementing measures to attract foreign investment, there is a wide system of incentives for attracting investment. A preferential tax was introduced for foreign investors.

Benefits and incentives were identified. Here's how:

- Enterprises with no less than $30 \%$ of the total exports of goods (works, services) are entitled to pay less taxes than twice the current rates, regardless of the form of ownership;

- are exempted from paying taxes on projects included in the state investment program for five years;

- the share of income from enterprises with foreign investment to expand production and upgrade technology was exempted from paying taxes;

- the ability to export products produced without permission;

- it is allowed to import property abroad without customs payments for making a contribution to the authorized capital of joint ventures and only foreign capital enterprises in Uzbekistan;

- Ensuring free access of individuals and legal entities, including foreigners, to the privatization of state property, including large-scale real estate sales. 
For the implementation of investment projects, it is planned to purchase and use land plots on a competitive basis. Along with this, foreign investors were guaranteed the right to free their assets from confiscation and confiscation. They have the opportunity to transfer their profits and other money abroad as a result of their activities, use the profits received in the republic as reinvestment and have unlimited amounts of money in any currency in the republican banks.

The attraction of foreign investment in the country's economy is one of the key elements of foreign economic activity. For this, first of all, it is necessary to create favorable conditions on the ground, to the infrastructure. Because if someone wants to use foreign investment in their business, it is necessary to create an infrastructure. Another way to attract foreign investment in the economy is to create joint ventures on the basis of existing plants and factories. In the second stage of economic reform, taking into account the results of the practice of attracting foreign investment, it is aimed at introducing a system of incentives for investments, taking into account that they have entered the most profitable sectors. To increase production, the task is to create an energy mechanism to stimulate the investment activity of enterprises and the population.

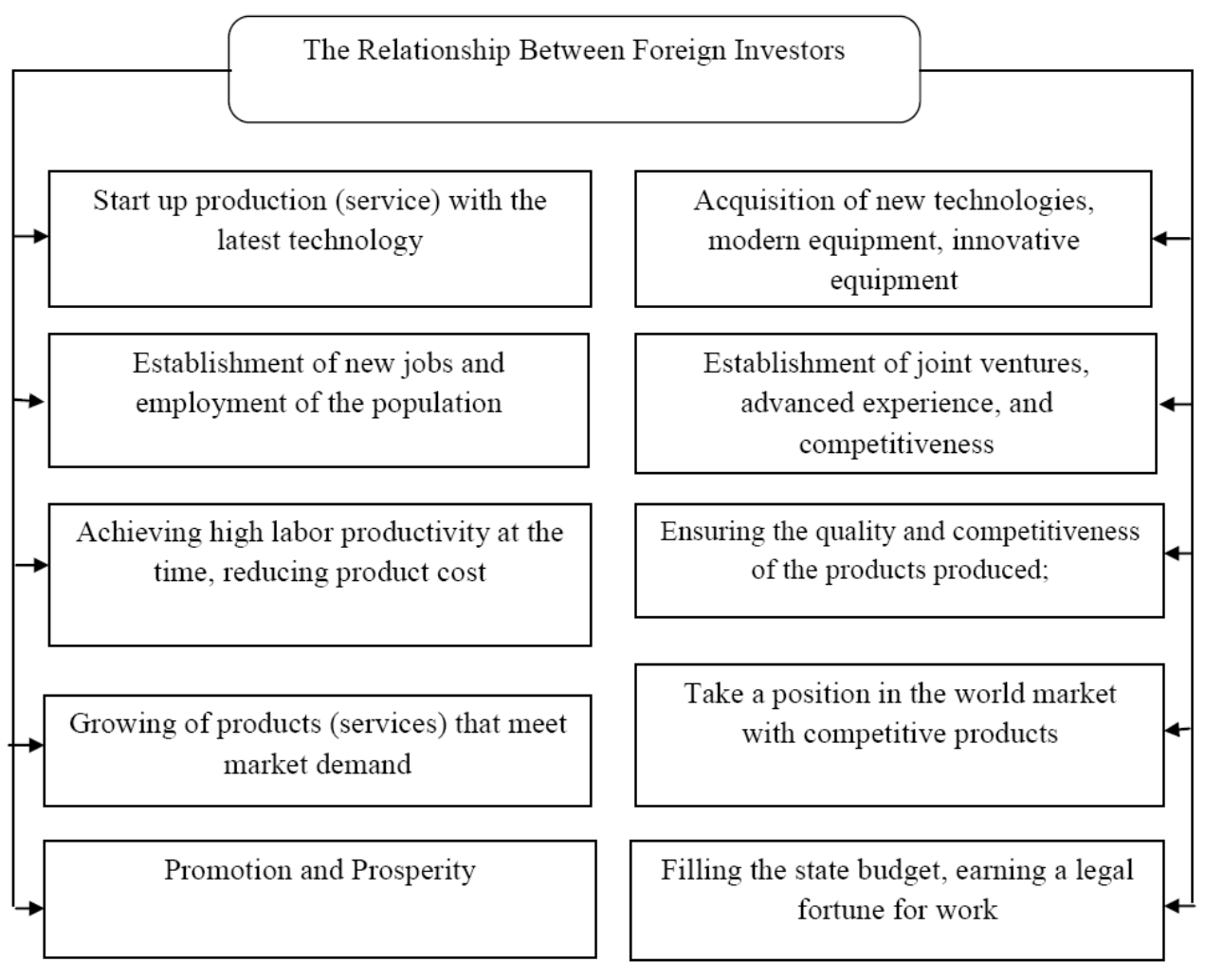

Fig. 2. The effect of foreign investment

The effectiveness of the foreign investment listed in Figure 2 can be maintained continuously because it will be possible to communicate with foreign partners, to work with them, to transform the structure of our national economy, to increase the country's power, strengthen the position of our national currency, improve welfare, and improve our lifestyle. Most importantly, each person expands his / her abilities, creates a basis for a happy life, ensures the wellbeing of the future generations; Uzbekistan rises to the number of developed countries, and becomes stronger and infinite.

The second phase of the reforms in our country focuses on the implementation of structural reforms in the economy and the production of competitive products based on the rapidly moving foreign investment. This can only be achieved through the mobilization of domestic investment and the extensive involvement of foreign investment.

Indeed, when it comes to association with foreign partners, of course, it is natural that they are primarily interested in other partner choices, even though they are willing to invest in common. Therefore, the president is encouraged to focus on domestic investment, in particular the mobilization of our domestic capital and the attraction of foreign investments.

Discussion of research results. The extent to which our government attracts foreign investment suggests that it will ultimately determine the future of our economy in many respects. It should be noted that the current state of our economy is largely dependent on how much we attract 
foreign investments today. In this regard, foreign investments will be focused primarily on introduction of new technologies and launch of new capacities.

When evaluating foreign investment, it is difficult and long-term to establish that it has to change its course on a competitive basis and increase the investment required [9], but there are potential losses, but capital increases, it can be said that the capital does not just go without moving.

Of course, everybody wants to do business, especially to invest in wealth. This, in turn, requires the creation of conditions for attracting investments. First of all, it depends on the political stability of the investor in the region and the fact that the laws and legal norms adopted in that country ensure that each owner of the capital guarantees profits and income. In addition, opportunities for investors in the region to invest in foreign direct investment, availability of skilled labor, resource prices, state of development of infrastructure, information reliability, availability of services, status and prospects of development of transport, and attractive projects are increasing.

Regulation of investment activity presupposes the principles of the formation of specific, complex, socially necessary economic (investment) relationships, from legal point of view, to reproduction of tangible and intangible assets among different proprietors. All subjects of the investment process - from foreign investors, state, juridical and physical, including foreigners, become participants in this relationship. From a legal perspective, foreign investments are associated with the possession, use and disposal of capital in another state. From economic point of view, they are likely to face many additional risks in order to benefit from their regional, time and place patterns.

Conclusions and Suggestions. The nature of investment relations is reflected in and within the scope of the participants. Presence of separate investment relationships reflecting objective conditions of development of investment activity necessitates an independent subject of regulation. From the point of view of legal regulation of investment activity, the norms of general legal and private legal regulation are covered. The unity of these principles represents the character and essence of social and private investment relationships and becomes a way of their regulation. The methods of regulation are the ways in which the legal norms will have a specific effect on the character of both individual and socially necessary investment relations.

Development and deepening of the investment base are defined as the most important prerequisites of the country's ongoing reform strategy, and it is necessary to implement these key priorities for the implementation of a strong investment policy:

- First of all, it is necessary to conduct a policy aimed at further liberalization of foreign economic activity. At the same time, the introduction of a more favorable procedure for the enjoyment of foreign investors' income in the export and import of goods;

- Secondly, further improvement of legal, socio-economic and other conditions for wide involvement of foreign investments in the form of direct capital investments into the national economy;

- Thirdly, implementation of open door policy towards foreign investors, which will help Uzbekistan to create a modern structure of national economy, bringing technology to world level;

- Fourthly, we need to invest in the development of the agrarian sector, the fuel and energy complex and other key sectors that support the most important sectors - the independence of the republic, the development of competitive, ready-made products. Because it is impossible to expand the export potential without re-structuring the economy.

\section{REFERENCES}

1. Vakhrin P. I., Neshitoy A. S. Investments: Textbook. - 3rd ed., Pererab. And add. - M.: Publishing and Trading Corporation "Dashkov and K", 2005. P.13.

2. Igoshin N. V. Investitsii. Organization of management and financing: Textbook for high schools. 2-e, pererab. i dop -M.: UNITI-DANA, 2001.S.81

3. Investitsii: Uchebnik / VV Valdaytsev, P.P. Vorobev et al.; Pod red. V. V. Kovaleva, V. V. Ivanova, V A Lyalina. -M.: TK Velbi, Izd-vo Prospekt, 2003. P

4. Melkumov Ya. S. Investment: Study Guide. -M.: INFRA-M, 2003. S.8.

5. Ivanov G. I. Investitsii. Vidy, Mechanism Functions / Series "Textbooks, tutorials", Rostov n / D: Phoenix, 2002. pp.24-25.

6. Zhdanov V. P. Investment mechanisms of regional development. -Kaliningrad, BIEF, 2001. P.121.

7. Stakhova L. V. Investment Management-M, 2001. P-356.

8. Sukharev O S, Shmanev S V, Kuryanovlar A M Economic evaluation of investments. Moscow: INFRA-M, 2006. -243 p.

9. Lawrence J. Gitman, Michael D. Johnk. Fundamentals of investment. -M.: Case, 2007, p.10. 